\title{
Impact of Short Term Irrigation with Different Water Types on Some Chemical and Physical Soil Properties
}

\author{
Basel Natsheh \\ Environment and Sustainable Agriculture Department, Faculty of Agricultural Science and Technology, Palestine Technical \\ University-Kadoorie, Tulkarm, Palestine \\ Email: b.natsheh@ptuk.edu.ps
}

How to cite this paper: Natsheh, B. (2021) Impact of Short Term Irrigation with Different Water Types on Some Chemical and Physical Soil Properties. Open Journal of Soil Science, 11, 389-401.

https://doi.org/10.4236/ojss.2021.118020

Received: July 14, 2021

Accepted: August 21, 2021

Published: August 24, 2021

Copyright $\odot 2021$ by author(s) and Scientific Research Publishing Inc. This work is licensed under the Creative Commons Attribution International License (CC BY 4.0).

http://creativecommons.org/licenses/by/4.0/

\begin{abstract}
The concern of this study is determine the quality of soil when irrigation used treated water and wastewater in comparison with soil irrigated with tap water on some chemical and physical soil properties. The experiment components were three trials carried out under greenhouse conditions, 10 pots for each trial. The first trial irrigated with tap water, the second trial irrigated by treated water and the third trial irrigated with wastewater. The experiment conducted to study the impact of water types on some soil physical and chemical properties. The experiment included important analysis for water and soil before and after irrigation. The results showed that the values for electrical conductivity (EC) were $0.850,308$ and $324 \mu \mathrm{s} / \mathrm{cm}$ for the treated soil with tap water, treated water and wastewater, respectively. The variation of $\mathrm{pH}$ values seems to be approximately constant between the different of water used. The percent of organic matter (OM) in soils receiving treated water and wastewater $4.7 \%$ and $5.2 \%$ respectively were higher than values in soil treated with tap water $3 \%$. The same trend was in organic carbon (OC) in soils receiving treated water and wastewater $58.5 \%$ and $89 \%$ respectively, while soil treated with tap water showed the lowest value $27.7 \%$. Soil particle density (SPD) increased significantly in both water treatments were the values was 2 $\mathrm{g} / \mathrm{cm}^{3}$ in tap water but increased value $2.8 \mathrm{~g} / \mathrm{cm}^{3}$ and $3.3 \mathrm{~g} / \mathrm{cm}^{3}$ in treated water and wastewater used respectively. The Bulk Density $(\mathrm{BD})$ values range 1.1 $\mathrm{g} / \mathrm{cm}^{3}$ in soil irrigated with tap water $1.5 \mathrm{~g} / \mathrm{cm}^{3}$ in soil irrigated with treated water and $1.85 \mathrm{~g} / \mathrm{cm}^{3}$ in soil irrigated with treated water. The results of soil analysis before and after planting showed that most of the values increased for the physical and chemical soil properties.
\end{abstract}

\section{Keywords}

Wastewater, Treated Water, Chemical Properties, Physical Properties, Soil 


\section{Introduction}

The shortage of fresh water resources is an ever-increasing concern worldwide. Particularly in the Middle East and North Africa, the availability of water is reaching critical levels and chronic water stress expected to continue to dominate the region [1] [2], with increasingly high demands for fresh water, sewage being considered as a valuable resource [3]. In recent years, the use of wastewater for agricultural irrigation has become increasingly common, particularly in water-scarce areas [4] [5] [6] [7]. Due to increasing interest in the use of sewage for irrigation and in light of the possible effects of sewage on agricultural soils and crop production, the influence of effluent irrigation on the physical, chemical, and biological properties of soil has been well-documented [8] [9] [10]. Previous studies have shown that sewage irrigation frequently accompanied by increases in macro- and micro-nutrients and heavy metals in the soil [11] [12], in addition to changes in soil microbial functional diversity and enzymatic activity [13] [14] [15]. Sewage irrigation can also increase the risk of crop and groundwater pollution [16] [17] and reduce soil quality and the infiltration rate [18].

One important feature of soil structure is the pore features, including number and size [19]. Soil pores, particularly macro pores (diam. $>1000 \mu \mathrm{m}$ ), play a critical role as preferential pathways for water, air and solutes through the soil profile [20] [21] [22]. Several studies have considered the effect of irrigation with sewage on soil water permeability. These studies have shown that the change in soil pores at the soil surface resulting from the swelling and dispersion of clays and accumulation of suspended solids results in a reduction in the infiltration rate or hydraulic conductivity.

Wastewater is recognized to have direct effect on soil chemical properties. It affects supply of mineral macro and micronutrients for plant growth, soil $\mathrm{pH}$, soil buffer capacity and soil CEC. Mohammad and Mazahreh [23] found at the end of the growing season that soil $\mathrm{pH}$ significantly lower when wastewater application and they attributed this decrease to the high content of ammonium in wastewater, which its nitrification would serve as a source of hydrogen ions thus causing a decrease in soil $\mathrm{pH}$. It also found that wastewater irrigation increased the level of soil salinity due to the wastewater salt content. Other researchers found that wastewater irrigations increased soil nitrogen $(\mathrm{N})$, phosphorus $(\mathrm{P})$ and potassium $(\mathrm{K})$, while heavy metal levels tended to generally increase in soil with increasing number of years of irrigation. In contrary, also they found that soil $(\mathrm{Zn})$ and $(\mathrm{Cu})$ not significantly affected by wastewater irrigation.

Arid and semiarid regions are characterized by evapo-transpiration that exceeds precipitation during most of the year. Therefore, agriculture in these regions relies on supplementary irrigation to enable productive crop growth. At the same time, one of the main environmental problems in these regions is a shortage of freshwater, which is expect to become more severe in the future because of the growing pressure on water resources, as well as climate change. Therefore, in these regions, one of the challenges facing agriculture, which 
commonly uses large amounts of water, is to find new sources of water for irrigation. One of the alternatives that have become more common in recent years is the reuse of treated domestic sewage (effluent) for irrigation. Currently, the effluent used for irrigation mainly obtained after secondary (biological) treatment. However, this effluent differs from freshwater in its salinity, sodicity, $\mathrm{pH}$, and concentrations of microelements, nutrients, dissolved organic matter (DOM), and total suspended solids (TSS), all of which are significantly higher than in freshwater. With regard to soil hydraulic properties, these differences in the quality of the effluent can affect water movement through the soil, either because of differences in the compositions of the percolating solutions, or because of changes in the chemical and physicochemical properties of the irrigated soil; changes that could affect soil structure [24].

The effects of irrigating with wastewater on soil chemical properties reported by many researchers [25] [26]. Moreover, the effects of irrigation on soil physicochemical properties in arid and semi-arid environments well documented. However, there is little information on the effects of small-scale irrigation on soil physicochemical properties in humid and sub-humid environment.

Research methodology to achieve the objectives of research work, there is a need to study and understand the fundamentals of the physical and chemical properties for soil (before and after agriculture) with use different sources of water. This take action by applying lab tests and analysis for soils, tap water, treated water and wastewater.

\section{Materials and Method}

The experiment conducted to study the effect of short-term irrigation with different water types (tap water, treated water and wastewater) on some chemical and physical soil properties. Three trials carried out under greenhouse conditions at Palestine Technical University (Kadoorie), Faculty of Agricultural Science and Technology, Department of Environment and Sustainable Agriculture. Cultivation of Cabbage crop started at 24 September 2019, the experiment components three trials included 10 pots for each trial. First trial irrigated by tap water, the second trial irrigated by treated water and the third trial irrigated by wastewater. Manual surface irrigation used until the crop harvested after 120 days from planting. The research methods involved collection of soil samples before and after agriculture to analyze in labs for selected parameters.

\subsection{Study Area}

Tulkarm is a Palestinian city located North West of the West Bank in the middle of the coastal plain. Tulkarm rise from the sea level from 55 meters west to 600 meters east, its land area is 32,610 dunum and is about $15 \mathrm{~km}$ from the Mediterranean coast. The site of the city historically a site of commercial and military importance has played a major role in the growth of the city. The location of 
Tulkarm characterized by soil fertility and abundant water availability, whether rain or rain, these conditions have led to a great growth and development of the city as shown in Figure 1.

\subsection{Soil Sampling: Physicochemical Parameters}

Soil samples irrigated with tap water, treated water and wastewater selected to compare the impact of water sources on soil. Soil used were collected from the university farm, soil divided to three groups according to different water types used. 30 samples of soils collected from all experimental units. The samples collected two different times before agriculture or planting and after harvested. The soil samples analyzed for the following Physical parameters: Soil Texture, Bulk Density, Soil moisture, hygroscopic water, particle density and porosity. The chemical parameters consisted of organic matter (OM), organic carbon (OC), Electrical conductivity (EC), sodium (Na), potassium (K), Phosphorus $(\mathrm{P})$ and $\mathrm{pH}$. Each soil sample taken for analysis after harvest consists of a mixture from 10 replicates to give a representative sample of the treatment with the type of water used.

1) $\mathrm{pH}$ determination $20 \mathrm{~g}$ of soil was soaked in $50 \mathrm{ml}$ distilled water and mixing well until dissolved. Leave the solution 16 hours. Then the $\mathrm{pH}$ was determined by using a $\mathrm{pH}$ meter after calibration [28].

2) Electrical conductivity (EC) determination $50 \mathrm{~g}$ of soil taken then drops from distilled water added with stirring until reaching saturation paste. Solution left 16 hours. Centrifuging at 1500 tour/min for $5 \mathrm{~min}$ done. Then we measured from supernatant with an EC meter at $25^{\circ} \mathrm{C}$ [28].

3) Sodium $(\mathrm{Na})$ and Potassium $(\mathrm{K})$ determination $4 \mathrm{~g}$ of soil dissolved in 100 $\mathrm{ml}$ of Ammonium acetate. Then the solution filtered. $\mathrm{Na}$ and $\mathrm{K}$ measured with a flame photometer [28].

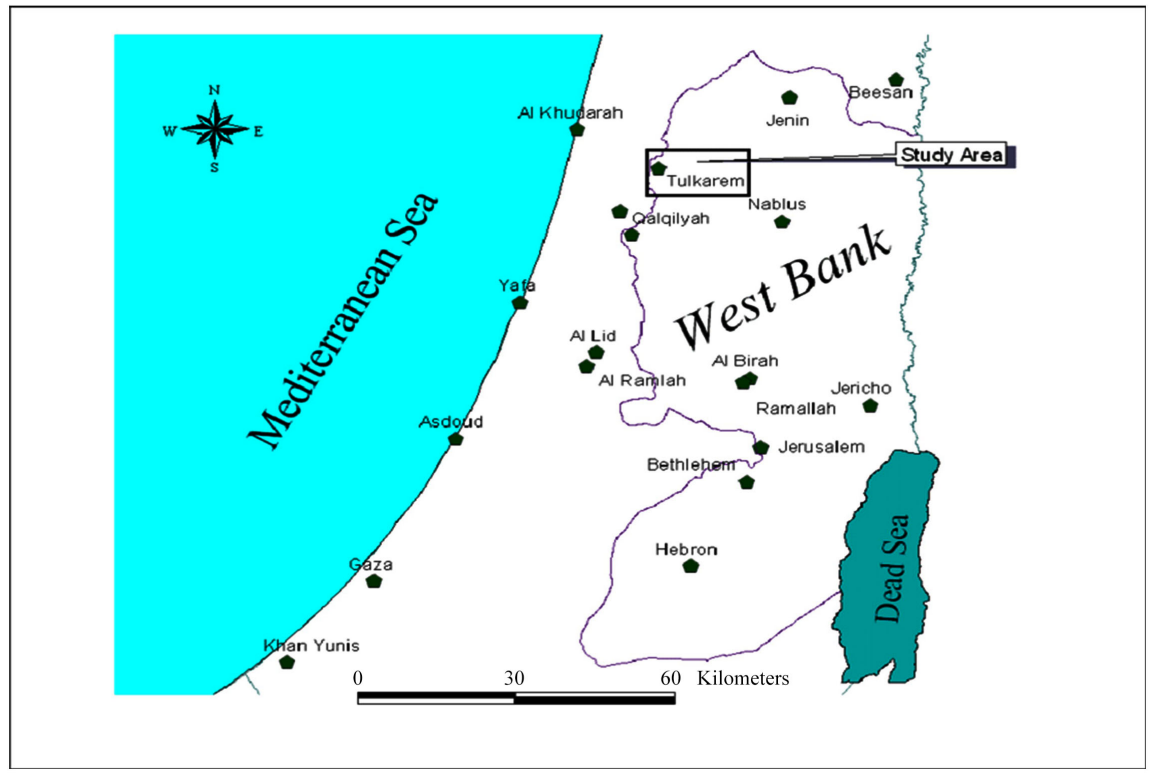

Figure 1. Tulkarm, west bank/palestine (Study Area) [27]. 
4) Phosphorus (P) determination $2.5 \mathrm{~g}$ of soil weighted in beaker $250 \mathrm{ml}$. Then $50 \mathrm{ml}\left(\mathrm{NaHCO}_{3}, 0.5 \mathrm{~N}\right.$ at $\left.\mathrm{pH} 8.5\right)$ added and the mixture then stirred in a reciprocating stirrer for 1 hour. The solution filtered through filter paper $<2 \mathrm{~m}$. Then (P) was determined by using a UV Visible Spectrophotometer at $825 \mathrm{~nm}$ [29].

5) Organic Matter determination $0.5^{-1} \mathrm{~g}$ of dry soil weighted in beaker $250 \mathrm{ml}$. Then $15 \mathrm{ml}$ (Potassium Bichromate, $\mathrm{K}_{2} \mathrm{Cr}_{2} \mathrm{O}_{7}$, solution $1 \mathrm{~N}$ ) was added and $20 \mathrm{ml}$ of $\mathrm{H}_{2} \mathrm{SO}_{4}$ acid. Then $50 \mathrm{ml}$ was titrated with Mohr's salt (0.5 N) [30].

\subsection{Layout of the Experiment}

The experiment carried out under greenhouse conditions at Palestine Technical University (Kadoorie), Faculty of agricultural Science and Technology, Department of Environment and Sustainable Agriculture collaboration with Laboratory agriculture research center (Kadoorie). Cultivation of Cabbage crop started at 24 September 2019, the experiment components were three trials included 10 pots for each trials illustrated in Figure 2.

\section{Results and Discussions}

\subsection{Water Analysis}

The results of water characteristics, in terms of some physical, chemical were determined for water samples analysis (Table 1). Characteristics of water used for irrigation in the experiment.

\subsection{Soil Analysis}

The soil quality tests analyzed for two types of quality characterizations, chemical and physical analysis as shown in Table 2. The method used to determine soil texture is a quantitative method using special soil sieves with meshes of different grades, a pre-weighed sample of dried soil put on top of a column of these sieves and shaken for 30 minutes. The soil collected in each progressively smaller mesh sieve is carefully collected and weighed, then distributions of various size, soil particles can calculated as a percent of the total weight of the sample.

Table 1. Characteristics of water used for irrigation in the experiment.

\begin{tabular}{cccc}
\hline & unit & Waste water Treated water \\
\hline Dissolved Oxygen (DO) & $\mathrm{mg} / \mathrm{L}$ & 3.8 & 6.2 \\
Total Suspended Solids (TSS) & $\mathrm{mg} / \mathrm{L}$ & 1270 & 380 \\
Total Dissolved Solids (TDS) & $\mathrm{mg} / \mathrm{L}$ & 1130 & 950 \\
Chemical Oxygen Demand (COD) & $\mathrm{mg} / \mathrm{L}$ & 720 & 340 \\
Biochemical Oxygen Demand (BOD) & $\mathrm{mg} / \mathrm{L}$ & 260 & 32 \\
Organic Carbon (OC) & $\mathrm{mg} / \mathrm{L}$ & 186 & 117 \\
Turbidity & $\mathrm{mg} / \mathrm{L}$ & 216 & 151 \\
Electrical Conductivity (EC) & MSemins & 1885 & 1730 \\
Sodium (Na) & Normal range $(6.5-8)$ & 7.5 & 8 \\
Potassium (K) & $\mathrm{mg} / \mathrm{L}$ & 62 & 58
\end{tabular}


Table 2. The results for physical and chemical soil analysis under different types of water source.

\begin{tabular}{|c|c|c|c|c|c|c|c|c|c|}
\hline \multirow[b]{2}{*}{ Soil treatments } & \multicolumn{8}{|c|}{ Physical analysis } & \\
\hline & Soil texture & $\begin{array}{c}\text { Hygroscopic } \\
\text { water } \%\end{array}$ & \multicolumn{2}{|r|}{$\begin{array}{c}\text { Soil } \\
\text { moisture \% }\end{array}$} & porosity & $\begin{array}{l}\text { Particle density } \\
\mathrm{g} / \mathrm{cm}^{3}\end{array}$ & $\begin{array}{l}\text { Bulk density } \\
\mathrm{g} / \mathrm{cm}^{3}\end{array}$ & $\begin{array}{l}\text { Specific } \\
\text { gravity }\end{array}$ & \\
\hline Before irrigation & clay & 1.8 & \multicolumn{2}{|r|}{19} & 45 & 1.8 & 1.0 & 1.03 & \\
\hline \multicolumn{10}{|c|}{ After irrigation } \\
\hline Tap water (T1) & clay & 2 & \multicolumn{2}{|r|}{20} & 47 & 2 & 1.1 & 1.09 & \\
\hline Treated water $(\mathrm{T} 2)$ & clay & 10 & \multicolumn{2}{|r|}{15} & 64 & 2.8 & 1.5 & 1.06 & \\
\hline \multirow[t]{3}{*}{ Wastewater (T3) } & clay & 9 & & 17 & 70 & 3.2 & 1.8 & 1.02 & \\
\hline & \multicolumn{8}{|c|}{ Chemical analysis } & \\
\hline & $\begin{array}{c}\text { Organic } \\
\text { matter \% }\end{array}$ & $\begin{array}{l}\text { Organic } \\
\text { carbon } \%\end{array}$ & $\begin{array}{c}\text { Total } \\
\text { nitrogen \% }\end{array}$ & \multicolumn{2}{|c|}{$\begin{array}{c}\mathrm{EC} \\
\mu \mathrm{s} / \mathrm{cm}\end{array}$} & $\mathrm{pH}$ & $\begin{array}{c}\mathrm{Na} \\
\mathrm{mg} / \mathrm{Kg}\end{array}$ & $\begin{array}{c}\mathrm{K} \\
\mathrm{mg} / \mathrm{kg}\end{array}$ & $\begin{array}{c}\mathrm{P} \\
\mathrm{ppm}\end{array}$ \\
\hline Before irrigation & 2.9 & 25.8 & 0.253 & \multicolumn{2}{|c|}{0.780} & 7.1 & 12.2 & 0.87 & 2.9 \\
\hline \multicolumn{10}{|c|}{ After irrigation } \\
\hline Tap water (T1) & 3 & 27.7 & 0.273 & \multicolumn{2}{|c|}{0.850} & 7.3 & 15 & 0.95 & 4.6 \\
\hline Treated water (T2) & 4.7 & 58.5 & 0.339 & \multicolumn{2}{|c|}{308} & 7.6 & 106 & 30.7 & 7.5 \\
\hline Wastewater (T3) & 5.2 & 89 & 0.476 & \multicolumn{2}{|c|}{324} & 7.9 & 113 & 32 & 7.6 \\
\hline
\end{tabular}

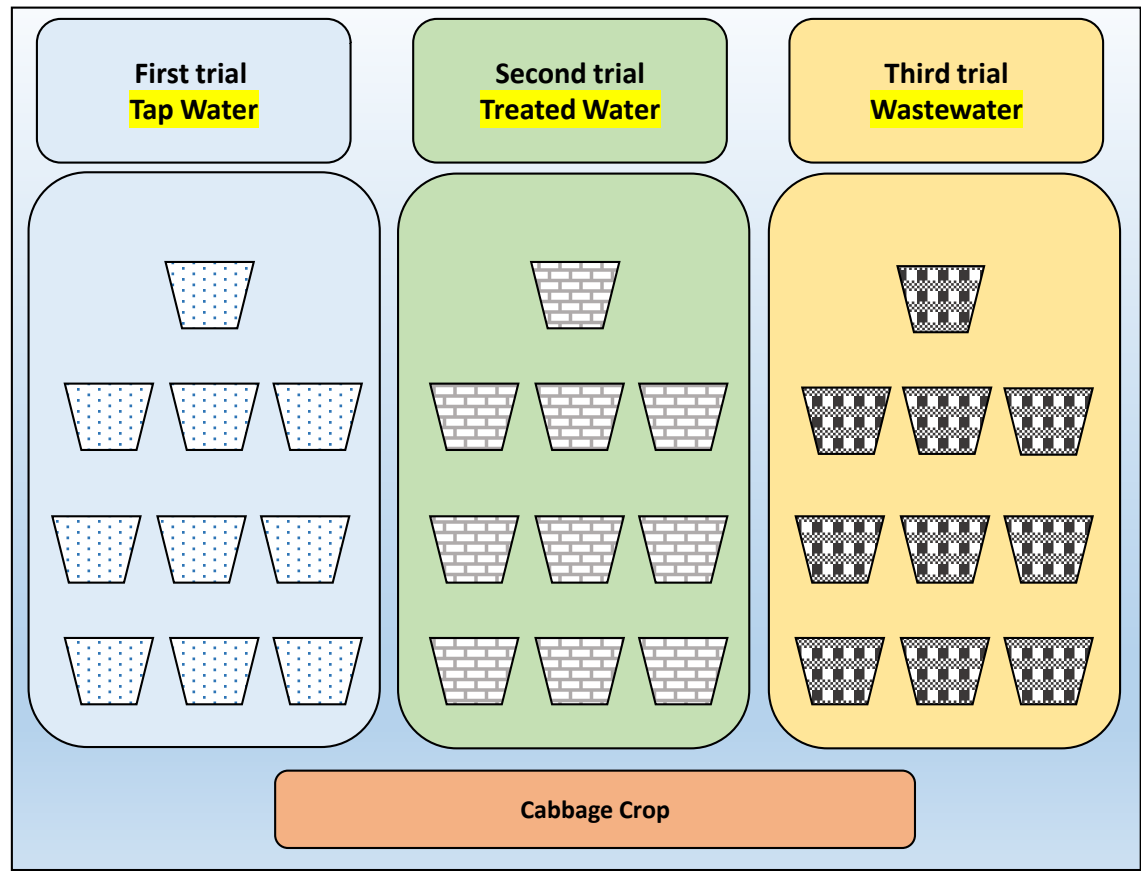

Figure 2. Design and format the experiment under greenhouse condition.

\subsubsection{Soil Chemical Analysis}

The variation of $\mathrm{pH}$ values seems different of water used, the $\mathrm{pH}$ lower value appear in the soil irrigation by tap water. Soil analysis showed that the soil $\mathrm{pH}$ ranged from 7.3 in tap water, 7.6 in soil irrigated by treated water and 7.9 in soil irrigated by wastewater. Soil $\mathrm{pH}$ directly affects the life and growth of plants because it affects the availability of all nutrients in the soil [15]. FAO, [31] these 
values considered slightly normal according to the limits recommended by [32]. Between pH 6.0 and 6.5, most plant nutrients are in their most available state [16]. Our result agrees with Mutengu et al., [33], Kiziloglu et al., [34]; Angin et al., [35] explained that the use of treated wastewater (TWW) for irrigation can have detrimental effects on soil quality.

Soil electrical conductivity (EC) is a measurement that correlates with soil properties that affect crop productivity, including soil texture, Cation exchange capacity (CEC), drainage conditions, organic matter level, salinity, and subsoil characteristics. The values for EC were $0.850 \mu \mathrm{s} / \mathrm{cm}$ in tap water, $308 \mu \mathrm{s} / \mathrm{cm}$ in treated water and $324 \mu \mathrm{s} / \mathrm{cm}$ for the soil treated with wastewater. Mean that the accumulated minerals in soil during the experiment under irrigation with treated water and wastewater. The EC explains the presence of salinity which is the most important indicator regarding to fields irrigated with wastewater [15]. Bratby [36] reported indeed to combat this salinity is possible by applying more normal water than the plant needs to remove the salts from the root zone by leaching [37].

The concentrations of $\mathrm{Na}$ in soils receiving treated water and wastewater were significantly higher than values in soil treated with tap water $106 \mathrm{ppm}, 113 \mathrm{ppm}$ compared to $15 \mathrm{ppm}$. The results also clarified the relationship between periodic time of grey water and wastewater applications and heavy metals accumulations in the soil. Minimum concentration of sodium obtained in the case of Bait alkasham [26] found such result. Soriano et al., [38] found Sodium is one of most concern among the specific toxic ions. It reported that sodium directly affects the availability of crop water and causes adverse physio-chemical changes in the soil, particularly to soil structure. It has the ability to disperse soil thus leading to decreased permeability, lowered shear strength and increased compressibility [39] [40].

Nitrogen $(\mathrm{N})$ In parallel, using wastewater led to improve total nitrogen in soil which was significantly high in soil irrigated with waste water with average of $0.476 \%$ compared to those irrigated with tab water $0.273 \%$. Akponikpe et al., [41] and Mutengu et al., [17], found similar results. It known that $\mathrm{N}$ and $\mathrm{P}$ are considered as the important macro nutrients that are required by crops for ample growth.

The percent of organic matter (OM) in soils receiving treated water and wastewater $4.7 \%$ and $5.2 \%$ respectively, higher than values in soil treated with tap water $3 \%$. The results also do show the relationship between periodic time of treated water and wastewater applications and OM accumulations in the soil, while the results of soil treated with tap water show the lowest value. The same trend was in organic carbon OC in soils receiving treated water and wastewater $58.5 \%$ and $89 \%$ respectively, while the results of soil treated with tap water show the lowest value $27.7 \%$. The organic matter is widely regarded as a vital component of soil fertility because of its role in physical, chemical and biological processes to supply the plants with the nutrients and helps soil to keep the 
moisture [22]. Valipour and Singh [42] reported the best amount of organic matter found in the soil irrigated with wastewater. It showed $2.00 \%$ compared to $0.74 \%$ obtained in the case of the soil irrigated with groundwater. This implies that wastewater contains organic matter compounds. This is in agreement with several studies, which have shown that (TWW) irrigation increases soil's organic matter [3] [23] [34] [43].

Phosphorus ( $\mathrm{P}$ ) Phosphorus considered one from the important nutrients that has direct effect on the growth and productivity of plant [24]. Average values of Phosphorus were high in soil irrigated with wastewater, $7.6 \mathrm{ppm}$, compared to $4.6 \mathrm{mg} / \mathrm{l}$ in soil irrigated with tab water. These results are consistent with those of Sacks and Bernstein [24] [44] and Akponikpe et al., [25] [41] have a sure indicator that (TWW) irrigation with wastewater increases soil phosphorus.

Potassium (K) Potassium considered the second important macro element for soil and crop productivity. It said that the effluent [16] [28] would supply potassium normally required for agricultural crop production [32] [45]. Results showed that irrigated soil with wastewater contains large amount of Potassium. It observed that there is increase in value of potassium $(\mathrm{K})$ in the soil irrigated with wastewater and treated water (32 and $30 \mathrm{mg} / \mathrm{kg}$ ) in comparison with $0.95 \mathrm{mg} / \mathrm{kg}$ in soil irrigated by tap water.

\subsubsection{Soil Physical Analysis}

Soil texture refers to the percentage by weight of sand (particles between 0.05 to $2.0 \mathrm{~mm})$, silt $(0.002$ to $0.05 \mathrm{~mm})$, and clay $(<0.002 \mathrm{~mm})$ in a soil sample. It based on that part of a field dried soil sample that passes through a 2-mm sieve. The type of soil particle (sand, silt or clay) that makes up the highest percentage of the sample used to describe the soil texture class. The conclusion about using treated water and wastewater for short term, as irrigation water in agriculture does not affected on soil texture.

Bulk density is an indicator of soil compaction. It is calculated as the dry weight of soil divided by its volume. This volume includes the volume of soil particles and the volume of pores among soil particles. Bulk density typically expressed in $\mathrm{g} / \mathrm{cm}^{3}$. Soil bulk density which irrigated by types of water were values increasing in soils irrigated with treated water and wastewater in comparison with soil irrigated with tap water. The values range $1.1 \mathrm{~g} / \mathrm{cm}^{3}$ in soil irrigated with tap water $1.5 \mathrm{~g} / \mathrm{cm}^{3}$ in soil irrigated with treated water and $1.85 \mathrm{~g} / \mathrm{cm}^{3}$ in soil irrigated with wastewater.

Porosity of surface soil typically decreases as particle size increases. This is due to soil aggregate formation in finer textured surface soils when subject to soil biological processes. Aggregation involves particulate adhesion and higher resistance to compaction. Typical bulk density of sandy soil is between 1.5 and 1.7 $\mathrm{g} / \mathrm{cm}^{3}$. This calculates to a porosity between $0.43 \%$ and $0.36 \%$. Typical bulk density of clay soil is between 1.1 and $1.3 \mathrm{~g} / \mathrm{cm}^{3}$. This calculates to a porosity between $0.58 \%$ and $0.51 \%$. The treated water and wastewater irrigation caused a reduction in the soil porosity; however, there was a significant difference be- 
tween the soil irrigated with tap water and wastewater irrigation treatments.

Soil particle density increased significantly in both water treatments. This was due to the particles dispersion and sedimentation of clay particles. Although the wastewater contains considerable organic matters were the values was $2 \mathrm{~g} / \mathrm{cm}^{3}$ in tap water but increased value $2.8 \mathrm{~g} / \mathrm{cm}^{3}$ and $3.3 \mathrm{~g} / \mathrm{cm}^{3}$ in treated water and wastewater used respectively.

Soil moisture content decreased according to the water type used were the values $20 \%$ in soil used tap water and decreased $15 \%$ were used treated water and reached $17 \%$ with using wastewater.

\section{Conclusion}

After evaluating the data collected from the experiment, it is clear that several types of irrigation e.g., treated water and wastewater play an important role in soil chemical and physical properties even for short time irrigation. The specific conclusions: soil $\mathrm{pH}$ remained within the normal range of 6.5 - 8 with an apparent decrease during dry season suggesting acid leaching. The wastewater irrigation caused a reduction in the soil porosity; however, there was no significant difference between (low effects for short time) the wastewater and groundwater irrigation treatments. The soil irrigated by treated water and wastewater increased the $\mathrm{BD}, \mathrm{PD}$, comparing with tap water irrigation. The result of most chemical properties showed that the soil parameters significantly affected by application of treated water and wastewater irrigation. Irrigation with wastewater increased the concentrations of electrical conductivity, $\mathrm{OC}, \mathrm{Na}$, and $\mathrm{K}$ in soils irrigated by sewage water compared to the ground water irrigation. Considering these results, we can concluded that using wastewater or treated water sources without adequate safeguards draw attention to several issues even if used for short time irrigation. The findings not allow nor recommended to the farmers and families in rural areas to continue reusing the wastewater without restricted irrigation, without apprehensive for long-term reuse. In addition, it recommended treat the wastewater in a good way before reuse it as agricultural irrigation with continuous soil analysis and testing.

\section{Acknowledgements}

The author would like to thank Palestine Technical University-Kadoorie (PTUK), also thanks to Palestinian Agriculture Relief Committee (PARC).

\section{Conflicts of Interest}

The author declares no conflicts of interest regarding the publication of this paper.

\section{References}

[1] Chen, Y., Lerner, O. and Tarchitzky, J. (2003) Hydraulic conductivity and soil hydrophobicity: effect of irrigation with reclaimed wastewater. In: 9th Nordic I HSS 
Symposium on Abundance and Functions of Natural Organic Matter Species in Soil and Water (ed. U. Lundstrom), p. 19. Mid-Sweden University, Sundsvall, Sweden.

[2] Tarchitzky, J., Lerner, O., Shani, U., Arye, G. and Brener, A. (2007) Water Distribution Pattern in Treated Wastewater Irrigated Soils: Hydrophobicity Effect. European Journal of Soil Science, 58, 573-588. https://doi.org/10.1111/j.1365-2389.2006.00845.x

[3] Hamilton, A.J., Stagnitti, F., Xiong, X., Kreidl, S.L., Benke, K.K. and Maher, P. (2007) Wastewater Irrigation: The State of Play. Vadose Zone Journal, 6, 823-840. https://doi.org/10.2136/vzj2007.0026

[4] Murtaza, G., Ghafoor, A., Qadir, M., Owens, G., Aziz, M.A. and Zia, M.H. (2010) Disposal and Use of Sewage on Agricultural Lands in Pakistan: A Review. Pedosphere, 20, 23-34. https://doi.org/10.1016/S1002-0160(09)60279-4

[5] Pedrero, F., Kalavrouziotis, I., Jose Alarcon, J., Koukoulakis, P. and Asano, T. (2010) Use of Treated Municipal Wastewater in Irrigated Agriculture-Review of Some Practices in Spain and Greece. Agricultural Water Management, 97, 1233-1241. https://doi.org/10.1016/j.agwat.2010.03.003

[6] Meena, R., Datta, S.P., Golui, D., Dwivedi, B.S. and Meena, M.C. (2016) Long-Term Impact of Sewage Irrigation on Soil Properties and Assessing Risk in Relation to Transfer of Metals to Human Food Chain. Environmental Science and Pollution Research, 23, 14269-14283. https://doi.org/10.1007/s11356-016-6556-X

[7] Shilpi, S., Seshadri, B., Sarkar, B., Bolan, N., Lamb, D. and Naidu, R. (2018) Comparative Values of Various Wastewater Streams as a Soil Nutrient Source. Chemos phere, 192, 272-281. https://doi.org/10.1016/j.chemosphere.2017.10.118

[8] Deshmukh, S.K., Singh, A.K., Datta, S.P. and Annapurna, K. (2011) Impact of Long-Term Wastewater Application on Microbiological Properties of Vadose Zone. Environmental Monitoring and Assessment, 175, 601-612. https://doi.org/10.1007/s10661-010-1554-9

[9] Rezapour, S. and Samadi, A. (2011) Soil Quality Response to Long-Term Wastewater Irrigation in Incept Sols from a Semi-Arid Environment. Nutrient Cycling in Agroecosystems, 91, 269-280. https://doi.org/10.1007/s10705-011-9460-2

[10] Tunc, T. and Sahin, U. (2015) The Changes in the Physical and Hydraulic Properties of a Loamy Soil under Irrigation with Simpler-Reclaimed Wastewaters. Agricultural Water Management, 158, 213-224. https://doi.org/10.1016/j.agwat.2015.05.012

[11] Meng, W., Wang, Z., Hu, B., Wang, Z., Li, H. and Goodman, R.C. (2016) Heavy Metals in Soil and Plants after Long-Term Sewage Irrigation at Tianjin China: A Case Study Assessment. Agricultural Water Management, 171, 153-161. https://doi.org/10.1016/j.agwat.2016.03.013

[12] Liu, B., Ma, X., Ai, S., Zhu, S., Zhang, W. and Zhang, Y. (2016) Spatial Distribution and Source Identification of Heavy Metals in Soils under Different Land Uses in a Sewage Irrigation Region, Northwest China. Journal of Soils and Sediments, 16, 1547-1556. https://doi.org/10.1007/s11368-016-1351-3

[13] Chen, L., Feng, Q., Li, C., Wei, Y., Zhao, Y., Feng, Y., Zheng, H., Li, F. and Li, H. (2017) Impacts of Aquaculture Wastewater Irrigation on Soil Microbial Functional Diversity and Community Structure in Arid Regions. Scientific Reports, 7, Article No. 11193. https://doi.org/10.1038/s41598-017-11678-Z

[14] Arif, M.S., Riaz, M., Shahzad, S.M., Yasmeen, T., Buttler, A., Garcia-Gil, J.C., Roohi, M. and Rasool, A. (2016) Contrasting Effects of Untreated Textile Wastewater onto the Soil Available Nitrogen-Phosphorus and Enzymatic Activities in Aridisol. Envi- 
ronmental Monitoring and Assessment, 188, 102.

https://doi.org/10.1007/s10661-016-5112-y

[15] Roohi, M., Riaz, M., Arif, M.S., Shahzad, S.M., Yasmeen, T., Ashraf, M.A., Riaz, M.A. and Mian, I.A. (2017) Low C/N Ratio Raw Textile Wastewater Reduced Labile $\mathrm{C}$ and Enhanced Organic-Inorganic $\mathrm{N}$ and Enzymatic Activities in a Semiarid Alkaline Soil. Environmental Science and Pollution Research, 24, 3456-3469.

https://doi.org/10.1007/s11356-016-8102-2

[16] Chen, J., Tang, C. and Yu, J. (2006) Use of O-18, H-2 and N-15 to Identify Nitrate Contamination of Groundwater in a Wastewater Irrigated Field near the City of Shijiazhuang, China. Journal of Hydrology, 326, 367-378.

https://doi.org/10.1016/j.jhydrol.2005.11.007

[17] Yadav, R.K., Minhas, P.S., Lal, K., Chaturvedi, R.K., Yadav, G. and Verma, T.P. (2015) Accumulation of Metals in Soils, Groundwater and Edible Parts of Crops Grown under Long-Term Irrigation with Sewage Mixed Industrial Effluents. Bulletin of Environmental Contamination and Toxicology, 95, 200-206. https://doi.org/10.1007/s00128-015-1547-z

[18] Lado, M. and Ben-Hur, M. (2009) Treated Domestic Sewage Irrigation Effects on Soil Hydraulic Properties in Arid and Semiarid Zones: A Review. Soil \& Tillage Research, 106, 152-163. https://doi.org/10.1016/j.still.2009.04.011

[19] Luo, L., Lin, H. and Li, S. (2010) Quantification of 3-D Soil Macro Pore Networks in Different Soil Types and Land Uses Using Computed Tomography. Journal of Hydrology, 393, 53-64. https://doi.org/10.1016/j.jhydrol.2010.03.031

[20] Udawatta, R.P. and Anderson, S.H. (2008) CT-Measured Pore Characteristics of Surface and Subsurface Soils Influenced by Agroforestry and Grass Buffers. Geoderma, 145, 381-389. https://doi.org/10.1016/j.geoderma.2008.04.004

[21] Meng, C., Niu, J., Li, X., Luo, Z., Du, X., Du, J., Lin, X. and Yu, X. (2017) Quantifying Soil Macro Pore Networks in Different Forest Communities Using Industrial Computed Tomography in a Mountainous Area of North China. Journal of Soils and Sediments, 17, 2357-2370. https://doi.org/10.1007/s11368-016-1441-2

[22] Halliwell, D.J., Barlow, K.M. and Nash, D.M. (2001) A Review of the Effects of Wastewater Sodium on Soil Physical Properties and Their Implications for Irrigation Systems. Soil Research, 39, 1259-1267. https://doi.org/10.1071/SR00047

[23] Mohammad, M.J. and Mazahreh, N. (2003) Changes in Soil Fertility Parameters in Response to Irrigation of Forage Crops with Secondary Treated Wastewater. Communications in Soil Science and Plant Analysis, 34, 1281-1294.

https://doi.org/10.1081/CSS-120020444

[24] Jaramillo, M. and Restrepo, I. (2017) Wastewater Reuse in Agriculture: A Review about Its Limitations and Benefits. Sustainability, 9, 1734. https://doi.org/10.3390/su9101734

[25] Itanna, F. (2003) Influence of Soil Type Differences on the Distribution of DTPA Extractable Heavy Metals in Soils Irrigated with Industrial Effluents. SINET Ethiopian Journal of Science, 26, 47-54. https://doi.org/10.4314/sinet.v26i1.18199

[26] Qian, Y.L. and Mecham, B. (2005) Long-Term Effect of Recycled Wastewater Irrigation on Soil Chemical Properties on Golf Course Fairways. American Society of Agronomy Journal, 97, 717-721. https://doi.org/10.2134/agronj2004.0140

[27] Amer, K. (2005) The Occurrence and Formation Potential of Trihalomethanes in Drinking and Recreational Water in Tulkarm District, Palestine, M.Sc. Thesis, p. $5-10$.

https://file:///C:/Users/microsoft/Downloads/AmerKanan_Mastertheses.pdf 
[28] Black, C.A., Evans, D.D., White, J.L., Ensminger, L.E. and Clark, F.E. (1965) Method of Soil Analysis. American Society of Agronomy, Inc., Wisconsin.

[29] Olsen, S.R., Cole, C.V., Watanabe, F.S. and Dean, L.A. (1954). Estimation of Available Phosphorus in Soils by Extraction with NaHCO. Circular No. 939 United States Department of Agriculture.

[30] Walkley, A. and Black, I.A. (1934) An Examination of the Degtjareff Method for Determining Soil Organic Matter, and a Proposed Modification of the Chromic Acid Titration Method. Soil science, 37, 29-38.

[31] FAO (2003) Users Manual for Irrigation with Treated Wastewater. Regional Office for the Near East, Cairo, Egypt.

[32] Pescod, M.B. (1992) Wastewater Treatment and Use in Agriculture. Other. Food and Agriculture Organization, Rome, Italy. Paper No. 4729.

http://eprints.icrisat.ac.in/id/eprint/8638.

[33] Mutengu, S., Hoko, Z. and Makoni, F.I.S. (2007) Physics and Chemistry of the Earth Part C: Solar, Terrestrial and Planetary Science, 32, 967-1412.

[34] Kiziloglu, F., Tuean, M., Sahin, U., Angin, I., Anapali, O. and Okuroglu, M. (2007) Effect of Wastewater Irrigation on Soil and Cabbage-Plant (Brassica Oleracea var. Capitate cv. Yalova-1) Chemival Properties. Journal of Plant Nutrition and Soil Science, 170, 166-172. https://doi.org/10.1002/jpln.200621971

[35] Angin, I., Yaganoglu, P. and Turan, M. (2005) Effects of Long-Term Wastewater Irrigation on Soil Properties. Journal of Sustainable Agriculture, 26, 31-42. https://doi.org/10.1300/J064v26n03_05

[36] Bratby, J., Schuler, P., Richards, M., Jimenez, J., and Petrik, K. (2006) A Rational Approach to Size Denitrification Filters to Meet TMDL Requirements. Proceedings of the Water Environment Federation, 2006, 3466-3478.

[37] Plaut, Z., Edelstein, M. and Ben-Hur, M. (2013) Overcoming Salinity Barriers to Crop Production Using Traditional Methods. Critical Reviews in Plant Sciences, 32, 250-291. https://doi.org/10.1080/07352689.2012.752236

[38] Soriano-Disla, J.M., Janik, L.J., Viscarra Rossel, R.A., Macdonald, L.M. and McLaughlin, M.J. (2014) The Performance of Visible, Near-, and Mid-Infrared Reflectance Spectroscopy for Prediction of Soil Physical, Chemical, and Biological Properties. Applied Spectroscopy Reviews, 49, 139-186.

https://doi.org/10.1080/05704928.2013.811081

[39] AL-Jasser, A.O. (2011) Saudi Wastewater Reuse Standards for Agricultural Irrigation: Riyadh Treatment Plants Effluent Compliance. Journal of King Saud University_Engineering Sciences, 23, 1-8. https://doi.org/10.1016/j.jksues.2009.06.001

[40] Chang, I.-S., Lee, E.W., Oh, S. and Kim, Y. (2005) Comparison of SAR (Sodium Adsorption Ratio) between RO and NF Processes for the Reclamation of Secondary Effluent. Water Science and Technology, 51, 313-318. https://doi.org/10.2166/wst.2005.0651

[41] Akponikpe, P., Wima, K., Yakouba, H. and Mermoud, A. (2011) Reuse of Domestic Wastewater Treated in Macrophyte Ponds to Irrigate Tomato and Eggplant in Semi-Arid West-Africa: Benefits and Risks. Agricultural Water Management, 98, 834-840.

[42] Valipour, M. and Singh, V.P. (2016) Global Experiences on Wastewater Irrigation: Challenges and Prospects. In: Balanced Urban Development: Options and Strategies for Liveable Cities, Springer, Cham, 289-327. https://doi.org/10.1007/978-3-319-28112-4_18

[43] Mañas, P., Castro, E. and Heras, J. (2009) Irrigation with Treated Wastewater: Ef- 
fects on Soil, Lettuce (Lactuca sativa L.) Crop and Dynamics of Microorganisms. Journal of Environmental Science and Health, Part A, 44, 1261-1273. https://doi.org/10.1080/10934520903140033

[44] Sacks, M. and Bernstein, N. (2011) Utilization of Reclaimed Wastewater for Irrigation of Field-Grown Melons by Surface and Subsurface Drip Irrigation. Israel Journal of Plant Sciences, 59, 159-169. https://doi.org/10.1560/IJPS.59.2-4.159

[45] Ndour, N., Baudoin, E., Guisse, A., Seck, M., Khouma, M. and Brauman, A. (2008) Impact of Irrigation Water Quality on Soil Nitrifying and Total Bacterial Communities. Biology and Fertility of Soils, 44, 797-803.

https://doi.org/10.1007/s00374-008-0285-3 